\title{
Accidents involving specialized aircraft in agriculture aerial spraying
}

\author{
Marcelo Boamorte Ravelli ${ }^{1}$ Cristiano Zerbato ${ }^{2}$ \\ Mailson Freire de Oliveira ${ }^{2}$ Rafael de Graff Corrêa ${ }^{2}$
}

${ }^{1}$ Departamento de Administração e Tecnologia (CAT), Universidade de Araraquara (UNIARA), 14801-340, Araraquara, SP, Brasil. E-mail: marcelobravelli@gmail.com. Corresponding author.

${ }^{2}$ Departamento de Engenharia Rural (DER), Faculdade de Ciências Agrárias e Veterinárias (FCAV), Universidade Estadual Paulista (UNESP), Jaboticabal, SP, Brasil.

\begin{abstract}
The great challenge for the practice of agricultural aviation has been to avoid accidents. Although, there are technological progress and high resources for safety, accidents continue to occur. The objective of this research was to analyze the influence and occurrence of factors in agricultural aviation accidents in Brazil recently. Based on research and technical - scientific papers written by researchers and aviation authorities, recommendations directed towards reducing the risks associated with this aircraft modality are assessed. The main factors responsible for accidents are normally operational errors and maneuvers that cause flight collisions, engine failures and altitude loss. Professional awareness and qualification converge towards the success of the agricultural pilot in the detection of inherent dangers or occasional in the various systems involved.

Key words: specialized aviation, agricultural aviation, danger, safety, training.
\end{abstract}

Acidentes com aeronaves especializadas em aplicações aéreas na agricultura

RESUMO: O grande desafio para a prática da aviação agrícola tem sido evitar acidentes. Ainda que haja progresso tecnológico e elevados recursos destinados à segurança, acidentes continuam acontecendo. O artigo analisa a influência e ocorrência dos fatores em acidentes aeroagrícolas ocorridos no Brasil recentemente. Com base em pesquisas e trabalhos técnico-cientificos elaborados por pesquisadores e autoridades de aviação, são avaliadas as recomendações direcionadas para reduzir os riscos inerentes a esta modalidade de aviação. Os principais fatores responsáveis pelos acidentes normalmente são erros de operação, manobras e falta de manutenção que ocasionam colisões de voo, falhas do motor e perda de altitude. A qualificação e conscientização do profissional convergem para o sucesso do piloto aeroagrícola na detecção de perigos inerentes ou esporádicos nos diversos sistemas envolvidos.

Palavras-chave: aviação especializada, aviação agrícola, capacitação, perigo, segurança.

\section{INTRODUCTION}

According to Ordinance No. 190/GC-5, dated March 20th, 2001 of Aeronautical Command, a Specialized Air Service (SAE) is every aeronautical activity other than public transport, covering agricultural aviation as an aerial activity with the purpose of protecting or promoting the development of agriculture in any of its aspects, through fertilizers, seeding, pest control and disease propagating agents, application of herbicides, defoliators and waters populating (BRASIL, 2001).

Even with the increase of technologies loaded onto aircraft in the current process, this advance still has problems, such as: lack of sufficient training for pilots, and their lack of awareness regarding the safe and proper use of aircraft.

In addition, as a reflection of this scenario, we have a significant reduction of the agricultural aircraft fleet useful life, a decrease in field efficiency and, especially, an increase in $t$ accidents occurrence.

With an agricultural aviation that stands out as being among the best in the world, Brazil's pilots are a fundamental factor in its success, whether it is in training and/or human qualities. Planes used by agricultural aviation companies with single-seat cabins, require a high workload from the agricultural pilot, from commander, gunner and even mechanic, demanding a flawless operation, without excesses or deficiencies. 
Agricultural aviation operation has inherent dangers, due to the low altitude it involves, subjecting the pilot to flying within the limits of the operating envelope of the aircraft, exposing him to potential unforeseen shocks and obstacles. Operating on unpaved and unmaintained runways with full load capacity, often without the required air space communication control, the pilot can perform up to 90 landings on the same day.

In this context, this research by the Brazilian Aeronautical Registry (RAB), National Civil Aviation Agency (ANAC) and Investigation and Prevention of Aviation Accidents Center (CENIPA) depicts the recent Brazilian profile of agricultural aircraft and accidents caused in this category.

Information obtained in this survey will provide access to data so that the whole community can devote their efforts to prevention of aviation accidents, making safety management more effective. The research was conducted in two major axes and relies on information obtained from 2013/14. The first axis deals with gathering information relating to the aircraft fleet used in agriculture. The second axis deals with information regarding agricultural aviation accidents and incidents obtained from records kept by the competent authorities.

"An occupational accident is what occurs when performing work for a company or by the carrying out of work by the insured persons referred to in section VII of Art. 11 of this law, causing bodily injury or functional disorder that leads to death, loss or reduction, permanent or temporary, of ability to work", as established in Law no. 6.195 of December 19th, 1974 and article 19 of Law no. 8.213/91.

Guidelines for prevention of accidents is defined by the Política Nacional de Aviação Civil (PNAC) and the Programa Brasileiro de Segurança Operacional da Aviação Civil (PSO-BR). Based on PNAC and PSO-BR, the Programa Específíco de Segurança Operacional para o Comando Aeronáutico (PSOE - COMAER) is established.

PSOE-COMAER provides instructions to the suppliers of air navigation services in the field of the Sistema de Gestão de Segurança Operacional (SGSO). Furthermore, it sets guidelines for prevention of aviation accidents in the Investigation and Sistema de Prevenção de Acidentes da Aviação (SIPAER).

\section{The agricultural aviation fleet}

The Agência Nacional de Aviação Civil (ANAC), the main unit responsible for information on aviation activities, provided data that classifies and quantifies the types of aircraft that constitute the fleets across the country. According to ARAÚJO (2014), the fleet was composed of 1925 "regular" and "irregular" agricultural aircraft by RAB, representing an increase of $6.29 \%$ of the fleet of December 2012.

1187 aircrafts manufactured nationally and 738 aircrafts manufactured abroad were registered, corresponding respectively to $61.66 \%$ and $38.34 \%$. The state of Mato Grosso continues to occupy the position of the largest fleet, with 446 aircrafts, followed by Rio Grande do Sul with 411, São Paulo with 268, Goiás with 234, Paraná with 138, and Mato Grosso do Sul with 95, followed by the remaining with smaller numbers. There was a growth of fleet in Bahia, registering the significant number of 92 aircrafts in 2013.

According to the same authors and their survey, in the ranking of manufacturers, EMBRAERNeiva is the manufacturer with the largest number of aircrafts registered, 1187 aircrafts. This manufacturer's main models are EMB-201A, EMB202 and EMB-202A. It is followed by Cessna, with 280 aircrafts (mainly model 188B - Agtruck), AirTractor, 224 aircrafts (mainly TA-502/TA-502B) and Piper with 141 aircrafts (PA-25-235 and PA-25-260). Aircrafts with turbines continue to increase strongly in the fleet, representing the vast majority of aircrafts imported throughout 2013. By the end of 2013, 210 turbo propeller aircrafts were registered, representing $10.91 \%$ of the total fleet.

\section{Characterization of accidents}

There are still a high number of agricultural aviation accidents in Brazil, which is incompatible with the evolution of aircrafts, application systems and training required by law of everyone involved in the activity. According to DRESCHER (2012), the exclusive concern with growing profits, the prevalence of the task over man or the disregard with his physical integrity which, occasionally, prevails in certain organizations, is continuously moving away the performance of tasks which represent a safe behavior.

The same author says that "the implementation of measures to detect and control risks in an agricultural aviation company is essential to minimize the risk of accidents; but although, deploying a safety management system may seem easy, it is not a quick and simple task. The proposal's great difficulty is the resistance of the work team. This resistance is not explicit, because nobody in 
their good conscience will oppose to the deployment of methods that propose to save lives and preserve material resources. In other words, the person resists without knowing it, by simply maintaining the attitudes that will endanger them."

Figure 1 represents the accident rate per category of aircraft, showing that the TPP category (private aviation service) makes up for a large part of accidents in the period 2004-2013, followed by the three categories with highest numbers of accidents, the PRI (private instruction), TPX (nonregular public transport) and S05 (private aviation service public specialized agricultural aviation) (ALMEIDA et al., 2016).

According to CENIPA, 31 occurrences were recorded in the country in 2013, an increase of $181 \%$ when compared to 2009 . In Rio Grande do Sul there were eight events in 2012, an increase of $167 \%$ compared to the recorded five years earlier.

Relevant factors responsible for the accidents are usually errors of operation and maneuvers that cause flight collisions, loss of altitude, calibration errors leading to deviations in the applications, deviations from the flight plan and engine failures, among other kinds of accidents.
The data presented in figures 2, 3 and 4 showed the analysis of all aviation, which included every type of aircraft, i.e. fixed or rotating wings. Therefore, this data does not faithfully represent the reality of agricultural aviation, which may present completely different indexes from those pointed out here.

In agricultural aviation, the most common causes registered in the occurrences are: collision against hilly terrain, fauna and flora, high-voltage networks, as well as operational conditions devoid of work quality (lack of employment, lack of personal protection equipment and pilot fatigue) and lack of quality of the aircrafts maintenance.

Figure 2 depicts the rate of accidents per type of occurrence, in which dry engine failure during flight and loss of control of aircraft represent the largest proportion of accidents with $40.93 \%$.

Surveys conducted by the organization Autoridade de Segurança da Aviação Civil (CASA) showed that, in Australia, 75\% of accidents and incidents involving collisions with wires occurred with electric or telephone lines that were previously known to pilots (CASA, 2014).

In the special case of agricultural aviation operations, due to its characteristics, it is observed that

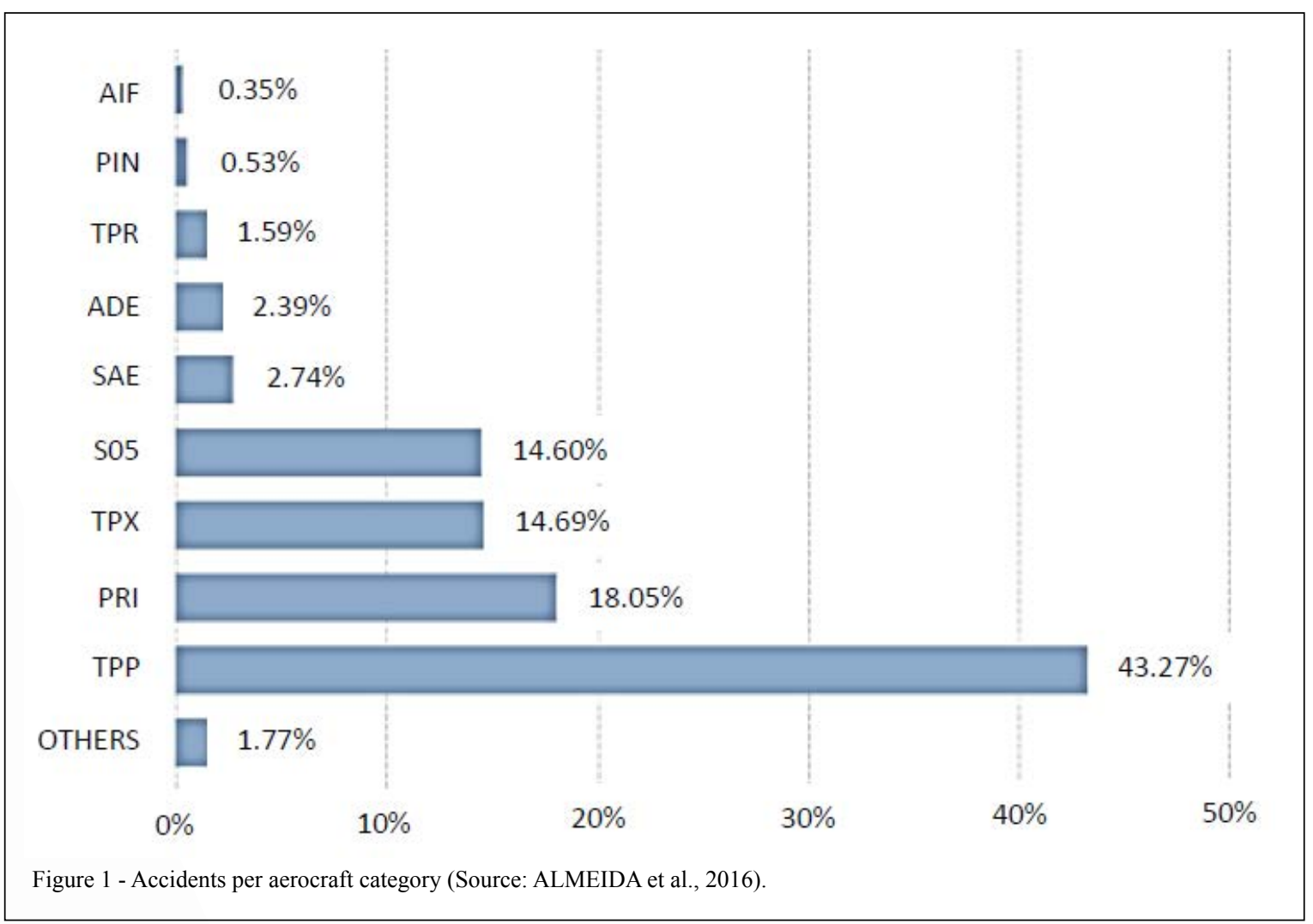

Ciência Rural, v.47, n.7, 2017. 


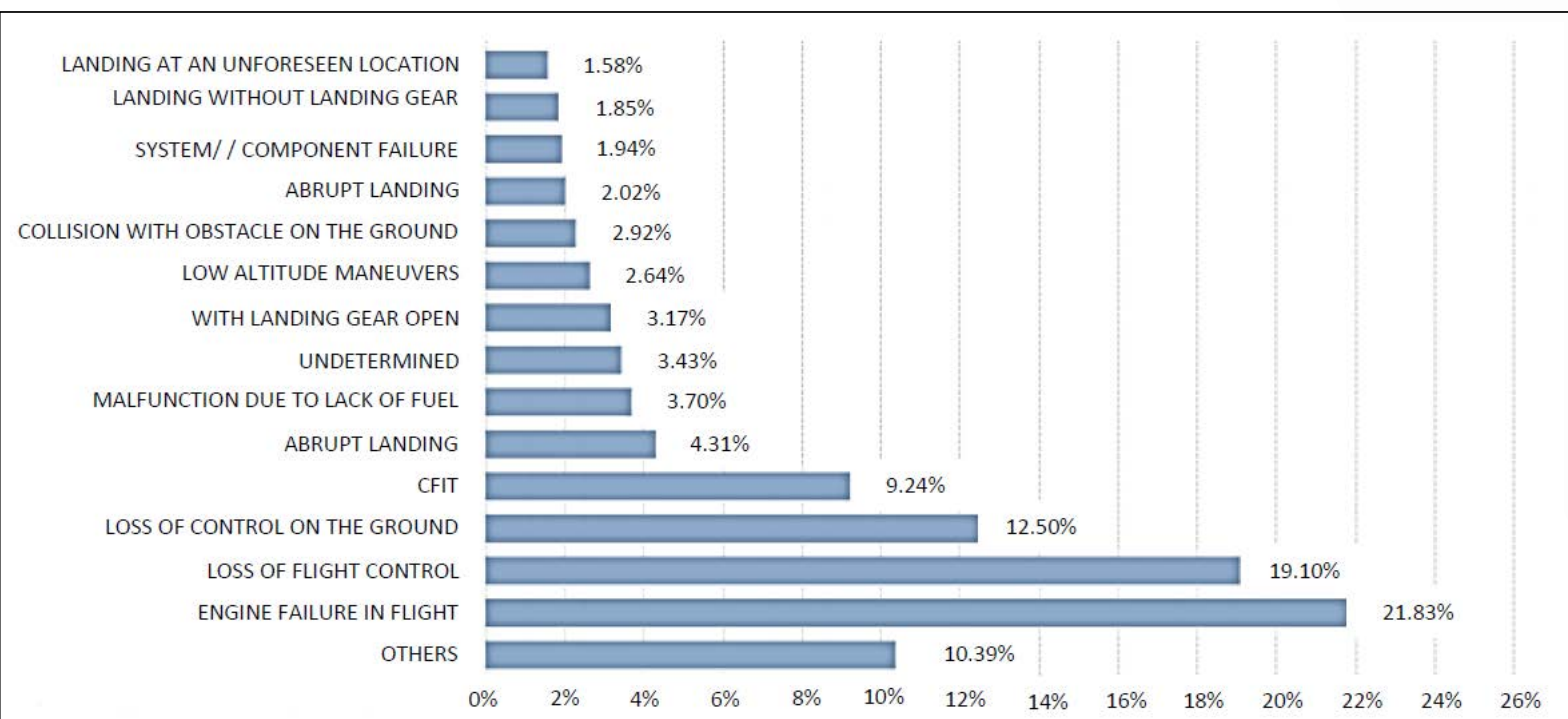

Figure 2 - Accidents per type of occurrence (Source: ALMEIDA et al., 2016).

it is very conducive to the occurrence of lapses because of the long daily journeys and the repetitiveness of "shots" and "balloons", maneuvers that can be performed frequently in one day (SIMÃO, 2010).

For REASON (1990), some errors are classified as "lapses". The author asserts that a necessary condition for the occurrence of this type of error is when something captures the individual's attention, associated to distraction or concern. The lapses appear in moments in which, after a decision, the action takes place without the need for greater mental effort; they appear; therefore, in routine and repetitive situations, that occur in a slightly automated manner.

According to RIBEIRO (2001), the degree of attention by the pilots will change according to their state of alertness and, consequently, with factors that determine it, such as their sleep and wakefulness cycle, general body, motivation for performing the task, level of expectation with regard to results and complexity inherent to the activity itself.

The high rate of contribution of the human factor, observed throughout the investigations into agricultural aviation accidents, has alerted to and demanded the intensification of preventive actions for this aviation segment, in order to prevent the accident rates accompanying the high growth trend of national agriculture (SIMÃO, 2010).

In recent years, in Brazilian agricultural aviation, human error has contributed decisively too many accidents and incidents associated with behaviors of excessive self-confidence, exhibitionism, compliance with violations and unsafe acts, improvisations, and non-compliance with standard procedure. The latter, in particular, is significantly noted in agricultural aviation, through the non-use of aircraft operating manuals by the pilots. This factor has been directly affecting the pilots' judgment on the flight profiles to be adopted and, especially, on the operational performance that the aircraft is capable to withstand (BRASIL, 2013).

The human factor is described as "the approach to flight safety that refers to the biological complexity of the human being, in its medical, psychological and operational aspects" (BRASIL, 2008a).

Research published by the Australian authority Australian Transport Safety Bureau (ATSB, 2004), similar to CENIPA, described that there are a number of factors that contribute to the distraction of the pilot. These factors are identified in four groups, according to ATSB: Visual distraction; Auditory distraction; Biomechanical (physical) distraction; Cognitive distraction ("lost in thought").

The Aviation Research Distraction Report B2004/0324 (ATSB, 2004) made the following recommendations: "Strategies to mitigate risks associated with travel at low altitudes depend mainly on the level of situational awareness maintained by the pilot. Among the techniques for an adequate level of consciousness are the attention to posts or any other physical structures that may indicate the presence of wires or obstacles; self-discipline; memory; pre-flight briefing; recognition and observation flight; piloting 


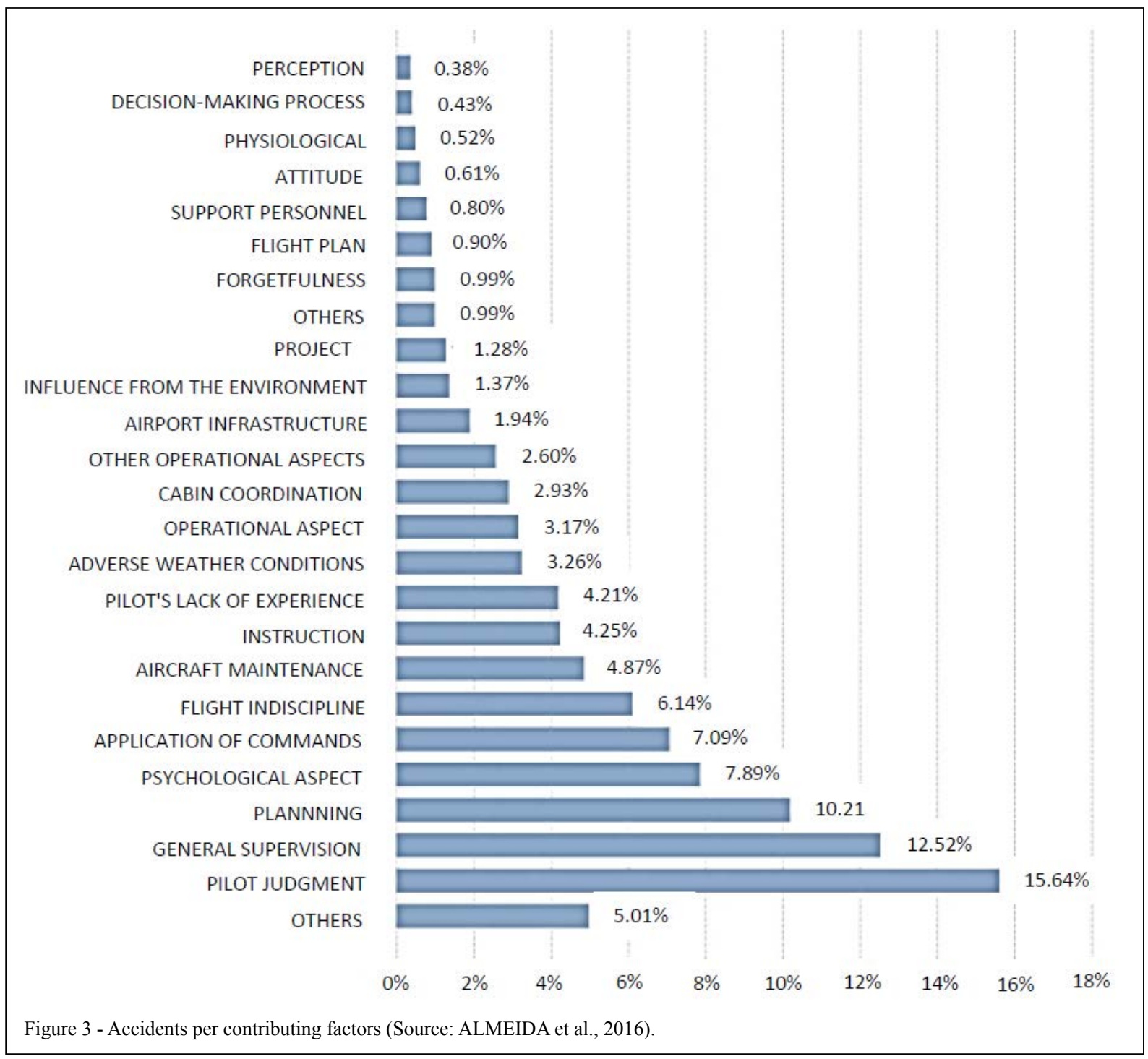

techniques; maintenance of good visual scanning and attention to climate conditions".

Agricultural Pilot Manual, published by Aerial Agricultural Association of Australia (AAAA, 2004), advises that "If there isn't anything to alert the pilot to the presence of wires in the area of application, it will be very easy to forget about the presence of these obstacles".

Thus, there is the development of another strategy to assist pilots in seeing the wires: high-voltage line markers. Figures $4 \mathrm{~A}$ and $\mathrm{B}$ show an example of a simple and easy-to-install marker developed jointly by Country Energy NSW (Australian electrical energy provider) and by Aerial Agricultural Association of Australia (FLIGHT SAFETY AUSTRALIA, 2006).
In Brazil, wire-cutting devices are installed on agricultural aircrafts, representing a defense to mitigate the consequences of collisions with wires. However, studies have shown that such devices sometimes did not work as expected, allowing the wire to resist enough to cause a change in the aircraft's flight direction, culminating in its fall. These obstacles' degree of hardness has proved to be relevant in this context (BRASIL, 2008b; 2008c).

COELHO \& MAGALHÃES (2001) and DRESCHER (2012), elaborating on the psychosocial factors that contribute to accidents around the globe, reported that a factor which can interfere in the pilot's decision-making is 


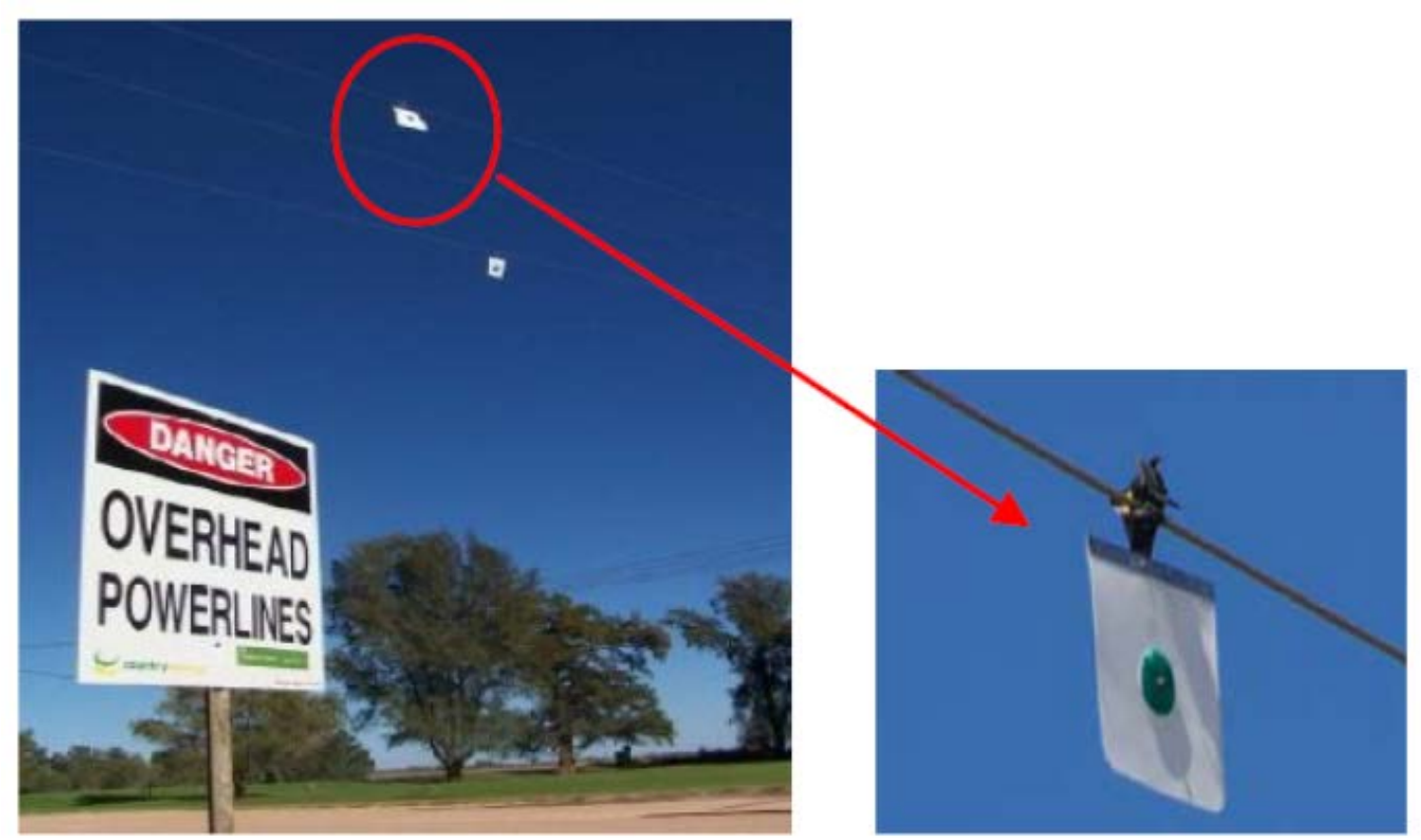

Figure 4 - A and B High voltage line markers (FLIGHT SAFETY AUSTRALIA, 2006).

the culture of the group or company of which he is a part of. If the company or group establishes the motto "continue flight while in an emergency that requires immediate landing", or "do not eject within the limit of operational safety height" or even "fulfill the mission at any cost" the pilot, so as not to feel discriminated by his colleagues, tends to react in accordance to the group thought, risking his life and the lives of others.

A study conducted by the FEDERAL AVIATION ADMINISTRATION (1991) showed that, due to the ground factor, agricultural flights which are too low (1 to 2 meters), produce a worse distribution of products than higher flights ( 3 meters). Test flights have enabled the pilot a better visualization of surroundings and obstacles, as well as giving him the opportunity to perform corrections of small losses of height. The best height for applications is approximately half the size of the aircraft - letter B of figure 5.

Another relevant factor to agricultural aircrafts is the loss of control during the flight, which accounts for more than $19 \%$ of accidents, as shown by the statistics (Figure 2). This factor can and is aggravated by pilot's attitudes and/or health situations which are not favorable to agricultural flight.

According to CENIPA Final Reports (BRASIL, 2008c; BRASIL, 2009), which showed that in both accidents the pilots died in the crash site in the midst of the hardware, the analysis of the medical aspect showed the pilots either suffered from hypertension and obesity and/or fatigue; moreover, one of them used medication restricted for air activity. These abnormalities may have reduced their tolerance to gravitational force ("G force") and interfered in their performance as a pilot.

Regarding the loss of control during a flight, the Advisory Circular 60-22, edited by FAA (1991), identified five dangerous attitudes which, when intensified, increase the risk of accidents, as shown in table 1.

From a cultural point of view, it is also important to note making bold maneuvers after the end of the daily work, when returning to the operational base, is, in some regions, a trivial situation. This can be confirmed by the number of accidents with the same characteristics in the area under the jurisdiction of SERIPA VI (DF, GO, MS, MT and TO) (BRASIL, 2009).

To complete the management and security mechanisms that must be carried out by the agricultural aviation companies, the Ministry of Agriculture along with the Brazilian Civil Aviation Regulations, ANAC - RBAC 137 (BRASIL, 2012) establishes and collects monthly reports of flight operations, helping to identify gaps and irregularities. 


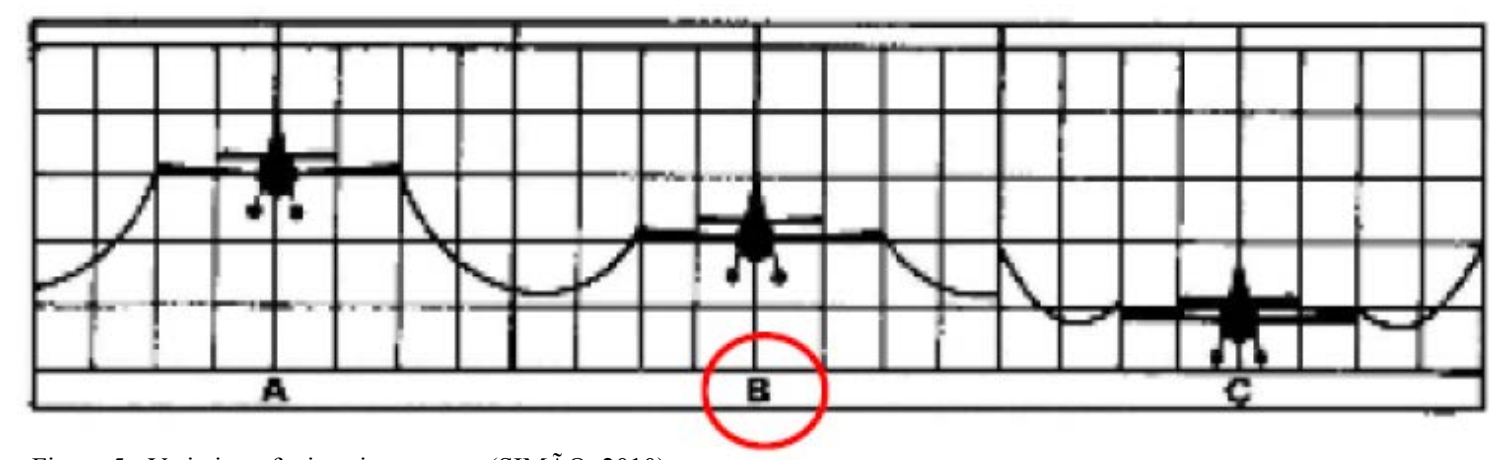

Figure 5 - Variation of wing-tip vortexes (SIMÃO, 2010).

\section{CONCLUSION}

Corporate earnings may not be at the expense of operational security. This creates situations that may expose the pilots to an unacceptable level of risk to the activity.

Even though the list of minimum equipment needed for the farming operation is included in the ANAC RBAC 137.209 regulation (BRASIL, 2012), it is important to remember that these operations are usually performed outside of controlled areas, which makes it impossible to supervise and enforce the Law with all offenders. ANAC has engaged in controlling whatever is within its reach and what really matters to society: the scheduled air transport of passengers. The reality that new pilots of aircrafts specialized in aerial applications in agriculture face when currently joining the activity, in a way, contradicts the evolution and technology we referred to earlier.

Because of this thinking, the maintenance of agricultural aircrafts is seen as of little importance to plantation owners, as the cost of servicing represents an increase in costs. Therefore, the problem will not be solved just trough punitive actions, because it may seem advantageous to pay fines rather than invest in prevention.

Another factor inherent to the lack of surveillance is its scope in many accidents and deaths caused by the activity when compared with other civil aviation activities, and could be considered of "low impact" for inspection agencies.

Operational safety should be achieved by complying with the agricultural aviation operation, respecting personal and aircraft boundaries, the atmospheric environment and bearing in mind that accidents can and should be avoided.

The qualification and professional awareness of pilots and the ground team converge in the success of the activity and the detection of inherent dangers.

Precaution of aeronautical accidents is a commitment for everyone and requires general participation. So in order to achieve a reduction in accidents it is necessary to better understand the contributing factors, which are indicators for management of flight safety in agricultural companies.

Table 1 - Dangerous attitudes during flights.

\begin{tabular}{lc}
\hline Dangerous Attitude & Characteristics \\
\hline Anti-authority & "Don't tell me what to do!", resistance to following orders and obeying rules. \\
Impulsiveness & "Do something now!", disregard for better alternatives. \\
Lack of vulnerability & "It won't happen to me!", denial of the risk given the circumstances. \\
Machismo & "I can do that!", an attempt to impress others. \\
Resignation & "What's the point?", gives up trying to influence others in the moment. \\
\hline
\end{tabular}

Source: Advisory Circular 60-22 (FAA, 1991).

Ciência Rural, v.47, n.7, 2017. 


\section{REFERENCES}

AERIAL AGRICULTURAL ASSOCIATION OF AUSTRALIA (AAAA) Dangerous Distraction: An examination of accidents and incidents involving pilot distraction in Australia between 1997 and 2004 (Aviation Research Investigation B2004/0324). Canberra, Australia, 2004.

ALMEIDA, C. A. et al. Ocorrências Aeronáuticas: Panorama Estatístico da Aviaçãoo Brasileira - Aviação Civil 2006-2015. Centro de Investigação e Prevenção de Acidentes Aeronáuticos (CENIPA). Brasília. 2016

ARAÚJO, E.C. Agronautas - Frota Aeroagrícola Brasileira 2013. Available from: <http://www.agronautas.com/estatisticas/aviacaoagricola-brasileira/frota-brasileira-de-aeronaves-agricolas-emdezembro-de-2013.html>. Accessed: Aug, 2014.

AUSTRALIAN TRANSPORT SAFETY BUREAU (ATSB), Aviation Research Distraction Report B2004/0324, 2004.

BRASIL. Comando da Aeronáutica. Ministério da Defesa. PORTARIA N'190/GC-5, DE 20 DE MARÇO DE 2001. Brasília, 2001. 8p.

BRASIL. Comando da Aeronáutica. Centro de Investigação e Prevenção de Acidentes Aeronáuticos - CENIPA. NSCA 3-1: conceituação de vocábulos, expressões e siglas de uso no SIPAER. Brasília, 2008a. 39p.

BRASIL. Comando da Aeronáutica. Sexto Serviço Regional de Investigação e Prevenção de Acidentes Aeronáuticos. Relatório de Investigação de Acidente Aeronáutico: Aeronave PT-URR. Brasília, 2008b. 49 p.

BRASIL. Comando da Aeronáutica. Sexto Serviço Regional de Investigação e Prevenção de Acidentes Aeronáuticos. Relatório de Investigação de Acidente Aeronáutico: Aeronave PT-UKA. Brasília, 2008c. 49 p.

BRASIL. Comando da Aeronáutica. Centro de Investigação e Prevenção de Acidentes Aeronáuticos. Relatório Final de Acidente Aeronáutico: Aeronave PT-GXD. Brasília, 2009. 12 p.
BRASIL. Agência Nacional de Aviação Civil. Certificação e Requisitos Operacionais: Operações Aeroagrícolas. RBAC n ${ }^{\circ} 137$. (Brasília), 2012.

BRASIL. Segundo Serviço Regional de Investigação e Prevenção de Acidente Aeronáuticos - SERIPA II. Boletim Informativo de Prevenção de Acidentes Aeronáuticos da Região Nordeste, Ano 2, n. 12,30 p. Ago. 2013.

CASA CIVIL AVIATION SAFETY AUTHORITY. Research and Statistics. First Published July 2012; Fully revised December 2014 (2nd edition). Available from: <file://C:/Users/Marcelo/Downloads/2014sms-book4-safety-assurance.pdf $>$. Accessed: May 2014.

COELHO, E.C.; MAGALHÃES, F.G. A influência dos aspectos psicológicos na segurança de voo. In: PEREIRA, M.C.; RIBEIRO, S.L.O. (Orgs.). Os voos da psicologia no Brasil: estudos e práticas na aviação. Rio de Janeiro: Departamento de Aviação Civil, 2001. 39 p.

DRESCHER, M. Manual de piloto agrícola. São Paulo: Bianch, 2012. 292 p.

FEDERAL AVIATION ADMINISTRATION. Advisory Circular 60-22 - Aeronautical Decision Making. Washington, 1991. Available fom: <http://rgl.faa.gov/regulatory_and_guidance library/rgadvisorycircular.nsf/0/ccdd54376bfdf5fd862569d10073 3983?opendocument>. Accessed: Aug. 2014.

FLIGHT SAFETY AUSTRALIA. Watch out for wires - how ag pilots can handle the ever-present threat of hitting a wire during low-level operations. November-December 2006. Available from: $<$ http://aod.casa.gov.au/fsa/2006/dec/38-39.pdf >. Accessed: Aug 2014.

REASON, J. Human Error. Cambridge University Press, 1990. 302 p.

RIBEIRO, S.L.O. A atividade aérea sob a perspectiva psicológica. In: PEREIRA, M.C.; RIBEIRO, S.L.O. (Orgs.). Os voos da psicologia no Brasil: estudos e práticas na aviação. Rio de Janeiro: Departamento de Aviação Civil, 2001. 49 p.

SIMÃO, A.C. Acidentes nas operações aeroagrícolas: análise do fator humano. Revista Conexão SIPAER, v.1, n.3, July, 39 p 2010. 